\title{
Advent of the Second Century of Pediatrics
}

\author{
PAUL G. QUIE \\ University of Minnesota, Minneapolis, Minnesota 55455
}

I have the great privilege this morning of leading off these pediatric "rites of spring" by delivering the American Pediatric Society presidential address. This meeting is a combination thanksgiving and birthday party. We are thankful for successes in each of our laboratories and clinics and for having an opportunity to share information with colleagues and friends during our 100th birthday party. Exchange of new research information is our primary purpose, but hopefully each of us will also find abundant opportunities for good fellowship and conversation during the next several days. When we get home all refreshed in spirit, we should be able to finish those manuscripts and apply again for richly-deserved research support.

Joseph St. Geme should be addressing you now, and each of us feels a deep personal loss that he is not here. Joe had capacity for warm friendship in abundant measure and was an inspirational and visionary leader for each of us individually. Joe also had a special joy and zest for pediatrics and provided leadership for nearly all the organized structures in our specialty. These contributions will be described more formally when the Joseph St. Geme Award is presented this afternoon, but I want all of us to reflect now and contemplate the joy and optimism we would have heard from Joe about the future during this "advent of the second century of pediatrics."

His words may have been similar to William Osler's at the birth of the society 100 years ago. Osler admonished his audience to "wrest from nature, secrets which may be available for the prevention and cure of disease. Observe the phenomenon of life in all its phases, normal and abnormal. Cultivate the reasoning faculty and use the science of experimentation to know the true from the false" (1). These two medical leaders who lived 100 years apart expected the very best from each of us.

A scientific revolution was occurring when our Society was in its infancy 100 years ago. The microbial etiologies of many diseases were being discovered. The bacterial species causing pneumonia, meningitis, and diarrhea were identified and the pathogenesis of disease processes and fundamentals of host defenses were being explored. The new fields at that time of biochemistry, pathology, and microbiology did indeed "wrest secrets from nature which became available for the prevention and cure of disease."

Remember, the birth of our Society was during the era of Louis Pasteur, as well as von Behring, Ehrlich, and Metchnikoff. What an exciting time that must have been for physicians involved in science.

The word centennial suggests a long time span; however, in some ways it is relatively short.

One of our pediatric colleagues and honorary member of the American Pediatric Society, Dr. Arvo H. Yllpo, celebrated his 100 th birthday in Finland last year. In a recent letter I received from Dr. Ylppo, he describes an especially interesting neonatology meeting he had recently attended. Consider that he was already walking when the American Pediatric Society began.

I mention this birthday to emphasize that many of you will be contributing to pediatrics during a majority of the years of the second century of our society. I hope reflection on your own personal contributions and potential for discovery for the welfare of children in the years ahead will be part of your enjoyment of our centennial symposium today. Your contributions will be part of the bicentennial celebration in 2088 .

One hundred years does make the American Pediatric Society a venerable parent, however, and we are blessed with many offspring.

Table 1 gives the names and dates of birth of our progeny. All are healthy and have grown in stature and wealth encouraging to a proud parent. Each has assumed an important and necessary role in American pediatrics.

I consider that these organizations reflect the fertility and virility of pediatrics in America and share a sense of pride with each of you in the organizational structure of our specialty. Some of the priorities of pediatrics are emphasized in greater degrees than others in these younger organizations. For example, clinical practice and government policy are major concerns of the Academy of Pediatrics. Pediatric education and the environment for research is primary for the Association of Department Chairmen. Qualifications and credentialing is a central concern of the Board of Pediatrics. The APS has been a permissive parent, but the strength of our pediatric family brings credit to us all. The underlying object for all of us in our respective pediatric organizations is concern for the welfare of children.

The following is a succinct statement describing the object and purpose of the American Pediatric Society. "To bring together men and women for the advancement of the study of children and their diseases. For the prevention of illness and the promotion of health in childhood. For the promotion of education and research. To honor those who by their contributions to pediatrics have aided in its advance." This annual meeting is a major venue for reporting our progress in accomplishing these objectives.

In reviewing past APS presidential addresses, I noted that several of our presidents warned against diluting scientific inquiry with political concerns. Other presidents warned of the dire consequences if we neglected political leadership. It seems to me that in our wonderfully democratic American way, no one has ever paid the least bit of attention to any presidential pronouncement whatsoever. After politely listening, we have all enjoyed the meetings, returned to our clinics and laboratories, and worked with freedom at what we like to do. Evidence for the success of this system will be the wonderfully rich offering of our research activities during the plenary sessions, poster sessions, and subspecialty programs of our meeting this week.

As you note from this program and those from the past several years, we are again in the midst of a scientific revolution as spectacular as 100 years ago. Discoveries in molecular biology and genetics are contributing to an understanding of physiology and producing remarkable products for specific therapy. Insulin, vaccines, human growth hormone, and the interferons are just a few of the products available through recombinant genetic techniques. Mapping of the entire human genome is accepted as a realistic goal for scientific effort. The potential of this biotechnical revolution for prevention and cure of disease is almost beyond comprehension.

Leaders in our pediatric societies recognized these opportunities several years ago and successfully launched the Pediatric Scientist Training Program, which I believe is an exemplary model for developing clinical research scientists. It is a wonderful 
Table 1. Offspring of the American Pediatric Society
Society for Pediatric Research

American Society of Pediatric Department Chairmen

American Board of Pediatrics

Ambulatory Pediatric Association

Association of Pediatric Program Directors
American Academy of Pediatrics
Founded in 1929

Founded in 1930

Founded in 1959

Founded in 1932

Founded in 1960

Founded in 1985 example of cooperation between government, industry, and academe. It has rigorous selection of trainee and trainer, with provision of adequate time and realistic reward for research trainees. It's exciting to contemplate our young Pediatric Scientist colleagues as junior faculty capable of utilizing powerful molecular tools for understanding fundamental processes of physiology, pathologic aberrations in disease, and potential therapy. The Pediatric Scientist Training Program is a model for each of us as we examine our own training activities in our pediatric departments and respective subspecialties. Our colleagues in internal medicine have described the clinical scientist as an "endangered species." I predict that internal medicine will soon emulate the Pediatric Scientist Training Program.

A common bond uniting founders of the American Pediatric Society a century ago was the realization that basic needs of children in the United States were not being met and leadership was needed to improve the welfare, and indeed the survival, of infants and children in this country. At the first meeting, Abraham Jacobi forcefully expressed his concern about malnutrition and epidemic infections among America's children. He stated that welfare of children should be the highest priority for people of the United States and emphasized the shameful neglect and political indifference toward children (2). Since then, national and local programs stimulated and lead by pediatricians, as well as economic and scientific advances, have improved the outlook for children in most parts of the United States, but the death rate of infants in many parts of the world has not changed very much since 1888 even though dramatic changes in communication and transportation have made most parts of the world even more accessible than many parts of our country were in the early years of our society.

It is clear that the world is our laboratory and our clinic population is the world's children. The best efforts of our pediatric leaders are needed as much today for the world's children as pediatric leaders were needed 100 years ago.

The present tragedy of the AIDS epidemic demonstrates the mysteries of the microbial world we live in, and dramatically demonstrates the interdependence of our world in terms of disease. Application of molecular techniques and worldwide cooperation has resulted in astonishing progress in understanding the Human Immunodeficiency Virus and hopefully will bring means of prevention and cure. However, as pointed out by Dr. Carpenter in his AAP address three days ago, the medical establishment bears responsibility for ignoring the increased deaths from a new and mysterious disease in central Africa in the 1970s. Intervention may have been possible sooner, preventing premature death of young people throughout the world.

AIDS is a dramatic disease that has captured the headlines, but it is estimated that more than 10 million children die from other preventable diseases each year. Each of us must work as hard as our founders to influence our own national government's priorities about the world's children. Political indifference about health needs of children is as shameful now as it was when our Society was founded.

One of the temptations of Society presidents is prediction of the future. Howard Pearson has called these the "futuristic" addresses (3). I will be a little futuristic now, but it is more a warning than a prediction. Opportunities for each of us to participate in the thrill of discovery and in the satisfaction of helping the less fortunate are available in abundant measure, but the structure of our enterprise is exceedingly fragile and requires constant vigilance. Remember that during the first few decades of our society, centers of excellence in medical science were not considered to be in the United States, but were in Vienna, Paris, Berlin, Geneva, and other European institutions. Our Society was nearly four decades old when this all changed. The national governments of European countries were preoccupied with support of an arms race during the early part of the century and their national resources were diverted from health and life to destruction and death. Those priorities impoverished the medical sciences as well as many other things and led directly to World War and its consequences. The tragedy of that "March of Folly" for countries is beyond calculation and still with us (4).

Think about the highest priority today of our government and so-called developed countries. Priorities of the leaders of the superpowers, at least, seem to be led by a primitive assumption that security is proportional to power of destruction. Again an arms race is consuming the resources of each country at an enormous rate. Do you realize that more than one third of the resources spent by the United States on arms since World War II have been spent in the last six years (5)? In 1987, more than $\$ 800$ billion were spent on arms and one in five scientists and engineers in our country worked on some aspect of the arms industry. Meanwhile, throughout the world, nearly 15 million children die each year and many more millions of children and their parents are chronically hungry (Fig. 1). These are statistics, but as Victor Sidel has said, "Remember, statistics are really people with the tears washed off" (6). The enormous waste of our earth's resources has resulted in neglect of health and nutrition. People are already living in the rubble of World War III.

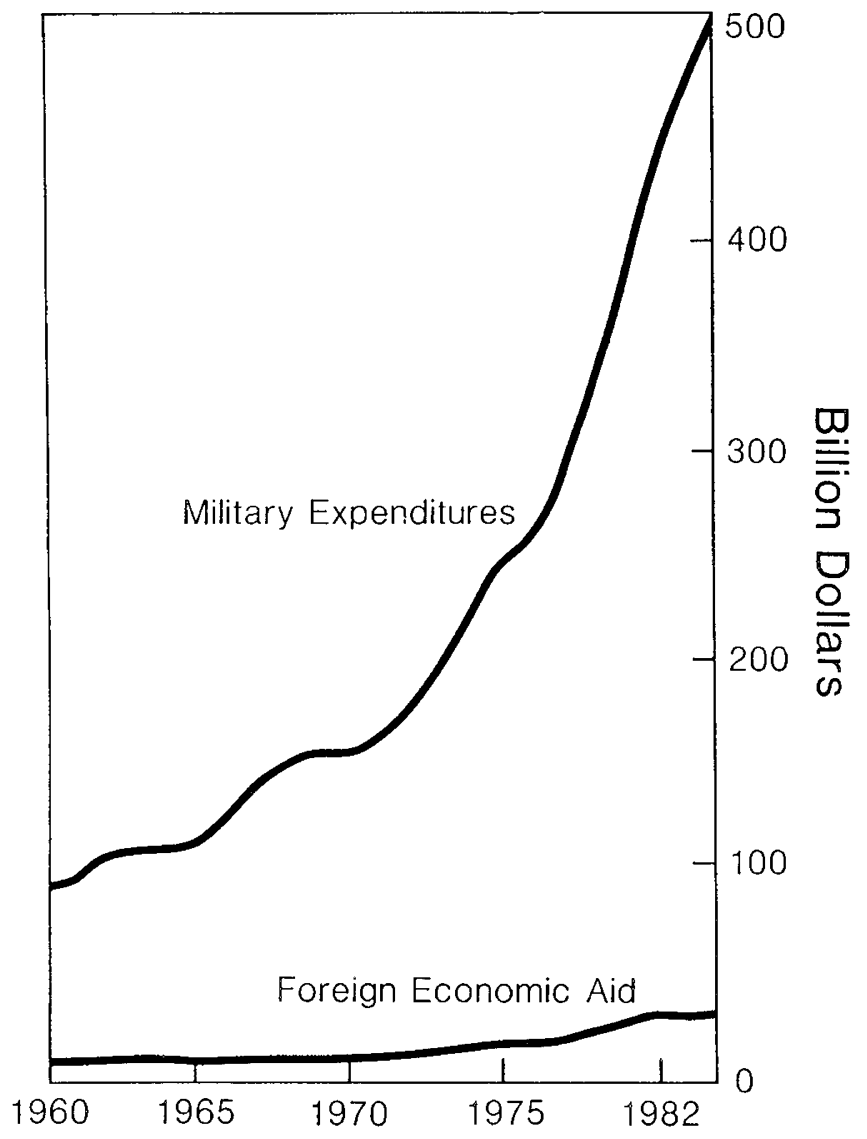

Ruth Leger Sivard, World Military and Social Expenditures 1983, World Priorities, Washington DC,1983

Fig. 1. "Kinetics": Military expenditures and foreign economic aid expenditures 1960-1982. 
George Kennan articulated so well what I am trying to say; I will quote him directly (7).

"This dreadful progression has gone hand in hand with a serious weakening of democracy in America. The military-industrial establishment has become the greatest single factor in our economic lives overshadowing and replacing constructive elements of the American economy. A discriminating view of relationships between the superpowers has fallen victim to regimes of oversimplification, exaggeration, and propagandistic distortion leading to an inability to relate military considerations realistically to other concerns of our society."

Thankfully, organizations such as UNICEF, World Health Organization, the World Bank, and the Rockefeller Foundation, as well as our pediatric institutions, are providing support for sustained immunization programs, and health care systems are slowly improving in some parts of the world.

All of us have enormous responsibility as citizens to make our voices heard on the arms race. Accepting that world resources continue to be used for improving methods of death is morally wrong. Paraphrasing the words of Albert Einstein 40 years ago, "A new way of thinking is required if our children, the children of the world, are going to benefit from the scientific revolution we are experiencing with its remarkable potential for health instead of all of us drifting toward catastrophe beyond comprehension" (8).

I am proud to say that pediatricians are one of the largest specialty groups in American medicine involved in activities to stop the present momentum of nuclear weapon proliferation and the arms race. This is not surprising, of course, since our ethic is promotion of health and prevention of disease. We, as pediatricians, have participated in successful, complex global programs such as small pox eradication. I expect we will hear this afternoon that eradication of polio and measles may be a gift of the 20 th century to the 21 st. We are used to thinking of millions and millions of lives; lives that have been made better, lives that are saved, and future lives that will be saved. People involved in these glorious achievements are our pediatric heroes; we will hear from some of them during our centennial celebration today!

My plea to all of us at this start of the second century of pediatrics is to accept personal responsibility as citizens, as well as pediatricians, for the welfare of the children of the world and the generations of children still to be born. Participate as vigorously as our founders, and we will be proud of wonderful achievements during our second century.

\section{REFERENCES}

1. Osler W 1986 Chauvinism in medicine (excerpt from collected essays of William Osler). JAMA 256:2588

2. Faber HK, McIntosh R (eds) 1966 History of the American Pediatric Society 1887-1965. McGraw Hill Book Co, New York

3. Pearson HA 1988 The Centennial History of the American Pediatric Society. Yale University Printing Service, New Haven, CT

4. Tuchman B 1984 March of Folly. Knopf Publishers, New York

5. Sivard RL 1983 World Military and Social Expenditures 1983. World Priorities, Washington, DC

6. Sidel VW 1985 Destruction before detonation. The impact of the arms race on health and health care. Lancet 2:1287-1289

7. Kennan GF 1987 Forward. In: Pathology of Power, Cousins N (ed). WW Norton Publishers, New York

8. Marsten RQ, Solomon F (eds) 1986 The Medical Implications of Nuclear War National Academy of Sciences Institute of Medicine. National Academy Press, Washington, DC 